purchasing and commissioning agencies. The guidelines are now avallable from the Royal College as Council Report Number 32. We would encourage members to obtain copies to ensure their wide dissemination. They offer an opportunity for the psychiatric profession to take the initiative in pressing for improvements in the clinical services in a major public health matter.

DAvid OWEnS and ALLAN House, Members of the Liaison Psychiatry Group, Royal College of Psychiatrists

\title{
The Mental Health Review Tribunal Service: applications for medical membership
}

The Mental Health Review Tribunal service is keen to increase the number of medical members, especially in and around London. and would welcome applications from psychiatrists interested in this area of work. Mental Health Review Tribunals have statutory responsibility for reviewing the cases of patients who have been compulsorily detained under the Mental Health Act 1983. Detained patients can seek a review of their case by applying to a Tribunal. Each Tribunal is made up of three part-time members, lay, medical and legal; the legal member acts as the chairman. Tribunals must consider whether it is necessary for the patient to continue to be compulsorily detained in hospital or whether other arrangements for care and treatment would be more appropriate.
Tribunals take place at the hospital where the patient is detained. Members must therefore be prepared to travel to these hospitals some of which are in remote locations. They will usually be expected to sit on at least two Tribunals at the hospital on the day. Each member is likely to sit no more than 50 days in a year.

Medical members receive a daily fee (under review) of $\$ 217.40$ plus expenses. The medical member is required to examine the patient before the hearing to form an opinion about the patient's mental state. This is usually carried out a day or so beforehand, for which a fee and expenses are also payable.

If you would like further details please contact Mrs Vanessa Cameron, College Secretary, for a background note and application form.

\section{List of Books Suitable for a Psychiatric Library 1994 (OP26)}

This bibliography, which offers book selection suggestions, is now available from the College Publications Department, price $£ 2.00$. 